\title{
FREI FRANCISCO DE SAN JUAN: UM MISSIONÁRIO ESPANHOL NA BAHIA EM 1624
}

\author{
POR \\ Pablo Antonio Iglesias Magalhães \\ Professor de História do Brasil I e História da América I \\ en la Faculdad de Tecnologia e Ciências de Salvador - EAD
}

\section{RESUMO}

O presente artigo divulga a existência de um manuscrito inédito sobre a invasão neerlandesa na Bahia em 1624. Seu autor é o missionário espanhol Frei Francisco de San Juan, que apresenta a melhor relação dos primeros meses da guerra, divulgando os detalhes desconhecidos da resistência contra os invasores até a morte do bispo D. Marcos Teixeira.

PALAVRAS CHAVES: Invasão neerlandesa no Brasil. Bispo Marcos Teixeira. Missões Espanholas.

\section{RESUMEN}

El presente artículo divulga la existencia de un manuscrito inédito sobre la invasión neerlandesa en la Bahia en 1624. Su autor es el misionario español Fray Francisco de San Juan, que presenta la mejor relación de los primeros meses de la guerra, divulgando los detalles desconocidos de la resistencia contra los invasores hasta la muerte del Obispo D. Marcos Teixeira.

PALABRAS CLAVE: Invasión neerlandesa en Brasil. Obispo Marcos Teixeira. Misiones Españolas.

\section{FRAY FRANCISCO DE SAN JUAN, A SPANISH MISSIONARY IN BAHIA IN 1624}

\begin{abstract}
The present article discloses the existence of an unpublished manuscript on the netherlandish invasion the Bahia in 1624. The author of the manuscript is a
\end{abstract}


Spanish missionary called Fray Francisco de San Juan, who presents the best relation of the first months of the war, disclosing unknown details of the resistance against the invaders until the death of the Bishop D. Marcos Teixeira.

KEY WORDS: Dutch Invasion in Brazil. Bishop Marcos Teixeira. Spanish Missions.

Recibido/Received 21-07-2009

Aceptado/Accepted 20-11-2010

As guerras neerlandesas no Brasil, iniciadas em 1624 com a ocupação de Salvador, na Bahia, é um dos assuntos mais investigados do período colonial. ${ }^{1}$ Nos seus aspectos gerais, este episódio é bastante conhecido aos historiadores brasileiros e europeus, mas nos seus aspectos particulares existem, entretanto, questões que carecem de investigação.

O expansionismo ultramarino das Províncias Unidas no século XVII foi consequência da redistribuição de poder entre as nações da Europa. Impulsionada pela atividade de banqueiros e comerciantes, pelo conceito de predestinação decorrente da confissão calvinista e pela guerra de independência contra a dinastia dos Habsburgo, que ocupava o trono da Espanha, as Provícias Unidas disputavam uma colocação entre as superpotências da época.

Naquele contexto de guerras, a escolha da Bahia como alvo da Companhia das Îndias Ocidentais (WIC) e dos Estados Gerais das Províncias Unidas teve motivações políticas e objetivos econômicos bem definidos: atacar a principal cidade portuguesa do Atlântico sul e dominar seu sistema produtor de açúcar. Em fins de 1623, a WIC e os Estados Gerais enviaram para conquistar Salvador uma armada com 36 navios, contando cerca de 3600 homens, sob o comando do almirante Jacob Willekens. O Governador Geral do Brasil, Diogo de Mendonça Furtado, que, em 1622, havia sucedido a D. Luís de Sousa, preveniu-se melhorando o sistema de fortificações na iminência do ataque, visto que Madrid não dispensava para a capital do Brasil os recursos necessários para sua defesa. Quando, a 9 de maio de 1624, a armada invasora apareceu diante de Salvador, rompendo fogo contra a cidade e contra os navios ancorados, a resis-

\footnotetext{
${ }^{1}$ Pablo Antonio Iglesias Magalhães, Equus Rusus: A Igreja Católica e as Guerras Neerlandesas na Bahia (1624-1654), Tese de Doutorado apresentada ao PPG em História da Universidade Federal da Bahia, 2010, Volume 3, pp. 4-26. Sobre a invasão da Bahia em 1624 existem diversos estudos, dentre os quais se podem destacar: George EDMUNDSON, «The Dutch Power in Brazil. The Struggle for Bahia 1624-1627» English Historical Review, Vol. XI, Oxford, 1896, pp. 231-259. Charles Ralph Boxer, The Dutch in Brazil, Oxford, 1954; Stuart B. Schwartz, «The Voyage of the Vassals: Royal Power, Noble Obligations, and Merchant Capital before the Portuguese Restoration of Independence, 16241640» The American Historical Review, Vol. 96, n. 3 (Jun, 1991), pp. 735-762. Neste artigo, Dr. Schwartz indicou a existência do presente relato, mas cometeu um equívoco paleográfico, trocando o nome do autor de «Francisco de São João» para «Francisco de São Brás». pp.740-743.
} 
tência se tornou impossível. Os moradores compreenderam que apenas as duas companhias de infantaria, contando menos de 180 homens, não poderiam resistir frente à superioridade numérica e tática dos invasores.

A despeito de alguma reação, a capital foi ocupada no dia seguinte, sendo Diogo de Mendonça preso e conduzido para a Holanda. No dia 11, o coronel Johan van Dorth assumia o governo da conquista em nome das Províncias Unidas, dirigindo um manifesto aos habitantes, convidando-os a confiar nas autoridades e a cooperar com os invasores.

À primeira vista, os moradores da Bahia mostraram-se tão impressionados com a violência do ataque à cidade, que os oficiais neerlandeses acreditaram ter feito uma conquista definitiva. Muito se têm discutido as causas que levaram os moradores a deserdar da cidade. O Bispo D. Marcos Teixeira e os principais oficiais civis evacuaram a cidade, após ter notícias de que parte considerável dos seus habitantes e dos militares já o fizera, seguindo para as aldeias jesuíticas do Recôncavo e do litoral norte da Bahia.

O Dr. Stuart Schwartz encontrou uma petição do jesuíta Damião Botelho, irmão do Bispo D. Marcos, ao governo espanhol, que foi indeferida sob a alegação da «Desajuda que [o Bispo] prestou na perda e na maneira como abandonou a cidade». ${ }^{2}$ Um manuscrito conservado na Biblioteca Universitária de Leiden, não obstante, afirma que o Bispo e os clérigos ofereceram auxílio militar ao Governador, que não os aceitou. Além disso, o prelado só decidiu abandonar a capital após os militares já terem saído, sendo que «o capitão Manuel Cardoso de Amaral (...) foi o primeiro». ${ }^{3}$ O Bispo foi questionado por um jesuíta pela razão de estar deixando a capital na madrugada do dia 10 de maio, ao que o prelado retrucou: «Eu, só, não posso defender a cidade». ${ }^{4}$ Os neerlandeses conquistaram Salvador aplicando o mínimo de força possível, mas invadir a capital, não obstante, foi mais fácil que assegurar a sua conquista.

Aproveitando-se do êxito garantido, mais que tudo, pelo pânico instalado, os neerlandeses foram ampliando seu raio de ação sobre outros pontos da costa. A maior parte dos navios da WIC deixou a Bahia, seguindo alguns para a Europa, carregados de despojos, e outros para Angola e o sul do Brasil, onde não encontraram as mesmas facilidades, sendo repelidos energicamente no Espírito Santo.

\footnotetext{
${ }^{2}$ Archivo General de Simancas, Sec. Prov. 1468. fls. 617-620. 1626. SchwarTZ, «The Voyage of the Vassals», pp. 740-741. MagalHães, Equus Rusus, Volume 1, capítulo 1.2.

${ }^{3}$ B. N. TeEnsma (ed.), Brasil Holandês: Tomo I: Dois manuscritos portugueses sobre a conquista neerlandesa-1624 e reconquista luso-espanhola-1625 de Salvador da Bahia, Rio de Janeiro, Index, 1999 , pp. 49 e 57.

4 Serafim Leite, História da Companhia de Jesus no Brasil, Rio de Janeiro, Imprensa Nacional, 1943. Vol. 5, p. 51
} 
Na Bahia, passado o primeiro susto, os moradores começaram a organizar a resistência. O Bispo D. Marcos Teixeira de Mendonça e parte dos oficiais militares passaram à aldeia do Espírito Santo, na atual vila de Abrantes. Segundo as vias de sucessão, na falta do Governador Geral, assumiria o Capitão-mor de Pernambuco, Matias de Albuquerque. Na ausência deste, os capitães locais indicaram o Ouvidor Geral Dr. Antão de Mesquita para o comando da guerra, mas por sua idade avançada foi substituído por eleição pelo Bispo D. Marcos Teixeira, que elaborou a traça da resistência e encarnou o espírito da contraofensiva aos hereges. Após a disputa de facções políticas que levou ao afastamento do Antão de Mesquita e com o apoio dos senhores de engenho do Recôncavo baiano, o Bispo D. Marcos Teixeira foi eleito comandante-em-chefe da resistência contra os neerlandeses.

Por terra, em três frentes, seguindo a defensável linha do Camurujipe, ${ }^{5}$ a cidade foi sitiada pelos luso-brasílicos e guerreiros tupinambá, que hostilizaram os neerlandeses com o objetivo de mantê-los isolados de qualquer modo de abastecimento. ${ }^{6}$ A essa altura, já começava a chegar ao Arraial do Rio Vermelho o socorro em mantimentos e munições, enviado pela Capitania de Pernambuco. O Coronel Johan Van Dorth foi morto durante uma missão de reconhecimento de perímetro e seu substituto, logo depois, faleceu de uma enfermidade. O fato é que a morte de Van Dorth desestabilizou gravemente a hierárquia e o comando das forças neerlandesas.

Ao dia 31 de julho de 1624 a notícia da tomada da Bahia chegou a Madrid, cinco dias depois de causar comoção política e religiosa em Lisboa. A corte de Madrid, afinal, resolveu agir e aprestou uma poderosa armada para restaurar a Bahia.

A armada compunha-se de quatro esquadras luso-espanholas, sob o comando de D. Fradique de Toledo e de D. Manuel de Menezes. Em fins de março de 1625, a Jornada dos Vassalos chegou à Baía de Todos os Santos e iniciou a operação de bloqueio naval e assalto por terra. A partir de 6 de abril de 1625, a luta tornou-se cada vez mais intensa e, segundo Frei Vicente do Salvador, testemunha dos fatos, registrou que «durante vinte e três dias não se passou um quarto de hora, de dia e de noite, sem que se ouvisse o estrondo de bombardas, esmerilhões e mosquetes, de parte a parte».

Os neerlandeses resistiram mas, um mês depois, a 30 de abril, assinam a capitulação, entregando a cidade do Salvador, além do armamento, munições, navios e escravos, retirando-se de volta para a Europa apenas com suas roupas e

\footnotetext{
${ }^{5}$ Rio Vermelho, na língua tupi.

${ }^{6}$ Sobre a ação dos aldeamentos jesuíticos na guerra contra os neerlandeses em 1624, ver: PARAíso, Maria Hilda Baqueiro PARAíso; Pablo Antonio Iglesias MAgalHãeS, «Muros do Recôncavo: a capital da América Portuguesa transferida para aldeamentos jesuíticos (1624-1625)» Revista CLIO 25.2 (Dossiê História dos Povos Indígenas), Recife, PPGH/UFPE, 2007, pp. 9-38.
} 
suprimentos para três meses de viagem. A $1^{\circ}$ de maio de 1625 , D. Fadrique de Toledo entrou em Salvador à frente dos luso-brasílicos e dos militares que participaram da Jornada dos Vassalos, apenas uma semana antes que o domínio neerlandês na capital completasse um ano. A vitória luso-espanhola gerou uma comoção político-religiosa na península ibérica em 1625 que despertou no público leitor o interesse por infomações sobre a Bahia, gerando dezenas de curtos relatos publicados em Portugal, Espanha, França, Províncias Unidas, Itália e até mesmo no México. Todos esses curtos relatos, impresos à época para celebrar a vitória da armada católica de El-Rey D. Felipe IV, ficaram limitados a descrever somente o final da guerra e as condições da capitulação imposta aos oficiais neerlandeses. ${ }^{7}$

Dois livros publicados logo após a reconquista da Bahia se destacaram como relatos oficiais da expedição, sendo o primeiro a Jornada dos Vassalos do jesuíta Bartolomeu Guerreiro, impresa em Lisboa ainda em fins de 1625, e o segundo a Restauracion de la Ciudad del Salvador do humanista D. Tomas Tamayo de Vargas, impresa em Madrid no ano de $1628 .{ }^{8}$ Nenhum destes dois cronistas embarcaram na expedição de reconquista e apenas recolheram os relatos de sacerdotes, militares e fidalgos que seguiram para o Brasil em 1625. Outras crônicas e relações que circularam manuscritas àquela época, publicadas somente no século XIX, apresentam as tensões políticas existentes entre Portugal e Espanha durante a União Ibérica, ${ }^{9}$ além de apontar as contradições em relação à participação de cristãos-novos na captura da Bahia ${ }^{10}$. Apesar desse extenso conjunto de manuscritos e publicações, nenhum enfoca o andamento da guerra e a organização da resistência no Recôncavo baiano em 1624.

Assim, os meses que compreendem a eleição do Bispo ao cargo de comandante das forças militares do Recôncavo baiano, em junho de 1624, à sua morte a 8 de outubro é o período menos documentado da guerra na Bahia. Sem des-

7 José Honório Rodrigues, Historiografia e Bibliografia do Domínio Holandês no Brasil, Rio de Janeiro, Instituto Nacional do Livro, 1949, pp.190 - 209.

${ }^{8}$ Bartolomeu Guerreiro, Jornada dos Vassalos da Coroa de Portugal, Lisboa, Mateus Pinheiro, 1625; Tomas Tamayo de VARGAS, Restauracion de la Ciudad del Salvador i Baìa de todos sanctos en la provincia del Brasil por las armas de don Fhilippe IV el Grande, Madrid, por la viuda de Alonso Martin, 1628.

${ }^{9}$ Juan de Valencia y GuZMAN, «Compendio Historial de la Jornada del Brasil y sucesos della» Colección de documentos inéditos para la historia de España, Vol. LV, Madrid, 1870; Manuel de MENEZES, «A Recuperação da Cidade do Salvador» Revista do Instituto Histórico e Geográfico Brasileiro, Tomo 22, Rio de Janeiro, 1859, pp. 357-411 e 527-633; «A Jornada dos Vassalos de D. Jerônimo de Ataíde em 1625» Magalhães, Equus Rusus, Vol. 3, 2010, pp. 27-61; Guida MARQues, L'Invention du Bresil entre deux monarchies: Gouvernement et pratiques politiques de l'Amérique portugaise dans l'union ibérique (1580-1640), Thèse pour obtenir le grade de Docteur, Ecole des Hautes Etudes en Sciences Sociales, 2009, pp. 81-121.

10 Eduardo D’Oliveira FrAnÇA, «Um problema: a traição dos cristãos-novos em 1624» Revista de História, n. 83, São Paulo, 1970, pp. 22-71. 
merecer os escritos de outras duas testemunhas da invasão de 1624, é certo que Antonio Vieira redigiu a Carta Ânua dois anos após a entrada dos neerlandeses e por mais brilhante que fosse, ainda era um rapazote de 17 anos que coloriu bastante o texto. Ademais, em 1624, Vieira não ficou na aldeia do Espírito Santo, seguindo com os demais noviços dos jesuítas para a aldeia de São João, afastada sete quilômetros da primeira.

O outro cronista da guerra, Fr. Vicente do Salvador, assistiu a invasão da Bahia do cárcere onde ficou confinado pelos oficiais neerlandeses, sendo libertado apenas quando a capital foi reconquistada. ${ }^{11}$ Até o presente, os únicos relatos escritos na aldeia do Espírito Santo no momento que foi organizada a contra-ofensiva foram as cartas escritas pelos jesuítas Manuel Fernandes e Miguel Rodrigues, datadas de 25 de julho e 18 de junho, respectivamente, conservadas no Archivum Romanum Societatis Iesu e publicadas por Serafim Leite em 1945. A carta do Padre Provincial Domingos Coelho foi escrita do cárcere na Holanda, em outubro, se reportando aos acontecimentos na Bahia até meados de julho de 1624.12

Existe, contudo, na Biblioteca Nacional da Espanha uma relação manuscrita por uma testemunha ocular que viveu em meio aos refugiados na aldeia do Espírito Santo, em 1624. A Relação de Fr. Francisco de São João narra o dia a dia no centro da resistência, as dificuldades dos refugiados e alguns pormenores desconhecidos pela historiografia da invasão holandesa. ${ }^{13}$

Em primeiro lugar, é necessário tecer algumas considerações acerca do autor da Relação. A presença de Fr. Francisco de São João na Bahia em 1624 foi completamente ignorada pelas crônicas e demais documentos relativos à invasão e retomada de Salvador em 1624 e 1625. Por pertencer à Ordem dos Franciscanos Menores, era de se esperar que os cronistas Fr. Vicente do Salvador e Fr. Santa Maria Jaboatão fizessem menção da sua presença na aldeia do Espírito Santo, mas não existe qualquer referência a este nome nos escritos de ambos.

As pesquisas em arquivos portugueses, ao exemplo do Cartório Franciscano na Torre do Tombo, não apontaram a existência de qualquer frade franciscano com este nome na primeira metade do século XVII vivendo em Portugal. Os principais cronistas das províncias franciscanas da Arrábida, de Santo Antonio e da Piedade também não mencionam a existência de frade da sua ordem com

\footnotetext{
${ }^{11}$ Antonio Vieira, Cartas do Padre António Vieira. (ed. João Lúcio de Azevedo.), Coimbra, 1925, v 1.pp. 3-47; Frei Vicente do SALVAdor, História do Brasil 1500 - 1627, São Paulo, Edições Melhoramentos, 1918.

12 LeITe, História da Companhia de Jesus no Brasil, Vol. 5, pp. 34, 48, 50-51.

${ }^{13}$ Biblioteca Nacional de España, Ms. 17533, «Da tomada da Cidade da Bahia, e o que mais sucedeu ate a morte do senhor Bispo», fls. 21 a $31 \mathrm{v}$.
}

Hispania Sacra, LXIII

127, enero-junio 2011, 155-184, ISSN: 0018-215-X 
este nome. Também não aparece em nenhum catálogo bibliográfico português ou brasileiro, de Diogo Barbosa Machado a Augusto Sacramento Blake, passando por Inocêncio Francisco da Silva.

A presença de Fr. Francisco de São João na Bahia durante a invasão neerlandesa permaneceu um enigma. A única pista, além do nome, existente no manuscrito, está na folha 30, quando o autor afirma «viam que lhe matavam aos nossos muita gente, que conforme diziam seriam os mortos perto de duzentos, e vivos alguns vinte, que por essas fazendas ficavão quando me vim para Espanha». Fr. Francisco de São João não retornou para Portugal, como era de se esperar de uma religioso português, mas seguiu em direção da Espanha.

Tratar-se-ia, então, de um Fray Francisco de San Juan? Isso explicaria a existência de muitos elementos da língua castelhana no manuscrito. O original desaparecido, aliás, provavelmente foi redigido em castelhano. A cópia do século XVIII conservada na Biblioteca Nacional de Espanha deve ter sido vertida para o português por anônimo copista, que aportuguesou, além do texto, o apelido do franciscano de San Juan para São João. Durante a cópia e tradução foram conservadas algumas palavras em sua forma castelhana, como o substantivo próprio «España», as preposições «en»e «con», que são recorrentes em diversos parágrafos, e as grafia «señor» e «otra» ao invés de «senhor» e «outra». Aparece também diversas vezes a conjunção castelhana «y», demonstrando falhas na tradução do original.

Foi necessário investigar a existência de algum Fr. Francisco de San Juan na Espanha da primeira metade do século XVII, sendo possível identificar dois franciscanos com este nome naquela época. O primeiro chamava-se Fr. Francisco de San Juan Evangelista e atuou nas missões franciscanas nas ilhas Filipinas. ${ }^{14}$ Do segundo Fr. Francisco de San Juan, atuante também em missões na Ásia, temos a seguinte informação: «Ignoramos su lugar de nacimiento, aunque sabemos que ingresó en la Orden en la Custodia de San Diego de México, pasando a Filipinas en 1592. Cinco años más tarde, 1597, emprendió viaje a Ja-

${ }^{14}$ Félix de Huerta, Estado Geográfico, Topográfico, Estadistico, Histórico-religioso, de la Santa y Apostólica Provincia de S. Gregorio Magno, de Religiosos Menores Descalzos de la... N.S.P.S. Francisco, en las Islas Filipinas, Binondo, Imp. de M. Sanchez y Ca, 1865, pp. 511 e 512 . «Biblioteca de Autores hijos de esta Provincia de S. Gregorio. 61. Fr. Francisco de San Juan Evangelista, Confesor, natural de Burgos de las Torres, de la ilustre famila de los Nietos y Silvas, profesó en la santa provincia observante de la Concepcion. No se sabe el año que llegó á Filipinas, pues no consta su nombre en las listas de misiones; pero en 25 de Agosto de 1633 ya se nombró ministro del pueblo de Cavinti y tambien outra vez á Morong. El año de 1645 estuvo de morador en Manila, y escribió: Tratado del gobierno espiritual de las monjas. Por los años de 1652 volvió á la administracion de Morong, y de aqui pasó á Caboan, donde enfermo, y retirandose á nuestro convento de Manila murió el año de 1656». 
pón para evangelizar en aquellas tierras». ${ }^{15}$ Os missionários franciscanos utilizavam o continente americano como ponte para alcançar as missões asiáticas, o que pode explicar a presença de frades espanhóis na Bahia, mas as Informações acerca de Fr. San Juan são demasiado esparsas para confirmar isto.

O fato é que, para além da afirmação de ter retornado para a Espanha, há apenas mais dois pronomes em primeira pessoa utilizados no texto da Relação por Fr. Francisco de San Juan. O franciscano, como quase todos os moradores, fugiu de Salvador para a aldeia do Espírito Santo a 9 de maio. Na folha 27 da Relação afirma que nos «primeiros dias padeceram muitas misérias (...) e que tres dias não soubemos que cousa era comer mais que uns pós de farinha de pão». Viveu na aldeia entre 11 de maio e meados de outubro, após a morte do Bispo, quando seguiu para a Espanha, onde deve ter chegado em fins de janeiro de 1625. Exatos quatro meses após a morte de D. Marcos Teixeira, os governadores da Portugal já consideravam apontar substituto para a mitra brasílica. ${ }^{16}$ É possível que a embarcação que levou o franciscano da Bahia para a Espanha tenha zarpado de Tatuapara, ${ }^{17}$ e feito escala em Portugal, ocasião em que seus passageiros podem ter informado ao governo as notícias da guerra na Bahia, inclusive a morte do Bispo.

$\mathrm{O}$ franciscano não redigiu seu texto na aldeia, visto que recorreu à sua memória para elaborar o testemunho. Ao concluí-lo, no verso folha 31, asseverou que «Isto é o que me lembra com toda a verdade, sem faltar um ponto de todo o que aqui digo». No verso da folha 28 afirmou que «de cento e vinte léguas veio um homem muito rico com oitenta homens somente ao servir», referindo-se a Salvador Correia de Sá e Benevides, que embracou no Rio de Janeiro para auxiliar a resistência na Bahia somente em fevereiro de 1625, quatro meses após o autor da Relação deixar o Brasil, indicando que o franciscano a escreveu por volta do segundo semestre de 1625, após obter essa informação dos que seguiram na Jornada dos Vassalos.

A relação abrange especialmente o período menos conhecido da organização da contra-ofensiva, entre junho e outubro de 1624. Apresenta notícias inéditas, não relatadas pelos outros cronistas neerlandeses ou luso-brasílicos, detalhando o envio de batéis com mensageiros neerlandeses ao Governador Diogo de Mendonça e Furtado antes do desembarque das tropas. Os luso-brasílicos perceberam que esta embaixada funcionaria como um «Cavalo-de-Tróia» e a repeliram.

\footnotetext{
15 Cayetano Sanchez FuERTES, «México, puente franciscano entre España y Filipinas», Actas del IV Congreso Internacional sobre los Franciscanos en el Nuevo Mundo (siglo XVIII) Cholula-Puebla, del 22 al 27 de julio de 1991, Madrid, Deimos, 1993, p. 384.

16 Arquivo Nacional da Torre do Tombo, Mesa de Consciências e Ordens, Livro 29 (1625-1627), fl.10, Lisboa, 8 de fevereiro de 1625 .

${ }^{17}$ Atual Praia do Forte, onde ainda hoje existem as ruínas da Casa da Torre de Garcia d’Ávila.
} 
A Relação guarda ainda uma surpresa aos leitores que conhecem as histórias da invasão neerlandesa de 1624. Dos escritos da época, é o único que afirma que o Bispo D. Marcos Teixeira não faleceu de causas naturais, mas que foi assassinado pelo médico responsável por lhe tratar de «umas quenturas». Existem duas biografias do referido Bispo, mas os seus autores, Wanderley de Araújo Pinho ${ }^{18}$ e Arlindo Rubert ${ }^{19}$ não conheceram as informações da presente Relação. No verso da folha 29, Fr. Francisco de San Juan afirma que um médico judeu isolou o prelado e «começou logo a sangrá-lo, a tirar sangue adonde o não havia, e logo lhe deu em tresválios de maneira que ao oitavo dia the deu uma purga, e ao décimo o enterrou, que todos disseram que lhe deram peçonha, e não podia ser menos, porque se viram muitas mostras de lha terem dada».

Antonio Vieira e Fr. Vicente do Salvador não apresentam esta versão da morte do bispo, mas o noviço estava na aldeia de São João e o antigo Guardião do Convento de São Francisco da Bahia aprisionado em um navio neerlandês. Os quatro principais cronistas ibéricos da Jornada dos Vassalos também não trataram neste assunto, visto que, quando a expedição chegou à Bahia, o Bispo já contava seis meses de sepultado. O Padre Guerreiro apenas diz que «em poucos dias lhe parou a vida, digna de mais largos anos». ${ }^{20}$ Apenas o dominicano Fr. Gaspar d'Acenção deu publica voz ao possível assassinato de D. Marcos Teixeira, questionando, no seu sermão que celebrou a vitória em 1625, «como se há de crer que matam os bispos?».21

Apesar de não ter sido publicada na Europa a notícia de que D. Marcos Teixeira foi envenenado, esta versão foi amplamente divulgada na Bahia. Existe outro documento que corrobora a acusação de Fr. Francisco de San Juan: as denunciações do licenciado Manoel Temudo da Fonseca nos Cadernos do Promotor da Inquisição de Lisboa. Cônego da Sé da Bahia, o licenciado Manuel Temudo da Fonseca nasceu em Sertam por volta de 1589 e embarcou para Salvador em 1623. No ano seguinte, acompanhou o Bispo D. Marcos Teixeira na aldeia do Espírito Santo e, depois, nas ações que partiram do Arraial do Rio Vermelho.

Após a morte do prelado em outubro de 1624 e a retomada da cidade em maio de 1625, Temudo foi instituído Governador do Bispado do Brasil, ocu-

\footnotetext{
${ }^{18}$ Wanderley de Araújo Pinho, D. Marcos Teixeira: Quinto Bispo do Brasil, Lisboa, AGC, 1940.

${ }^{19}$ Arlindo RUbert, «O Bispo D. Marcos Teixeira» Manoel de Aquino BARBosa (Org.), Freguesia da Conceição da Praia 1623-1973: Dom Marcos Teixeira, Fundador, Salvador, Typ. Beneditina, 1973.

${ }^{20}$ Bartolomeu Guerreiro, Jornada dos Vassalos da Coroa de Portugal, Lisboa, Mateus Pinheiro, 1625.p. 74 .

${ }^{21}$ Gaspar D’Ascenção, Serman que pregou o padre frei Gaspar Dasceção de Ordem dos Pregadores na Sé da Bahia de Todos os Santos na cidade de Salvador na primeira missa que se disse, quando se deram as primeiras graças publicas, entrada a cidade pela vitória alcançada dos Holandeses a 5 de Maio de 1625, Lisboa, Geraldo da Vinha, 1625, fl. 13.
} 
pando o cargo até 1631, quando retornou para Lisboa. Em 1632 conheceu o Bispo D. Pedro da Silva e Sampaio para quem relatou informações acerca da Bahia, dos seus moradores, da religião e, principalmente, do perigo que representava para o Brasil a presença dos neerlandeses e judaizantes. Temudo morreu em 1652, mas teve sua obra jurídica Decisiones et quaestiones Senatus Archiepiscopalis Metropolis Olysiponensi aplaudida por D. Francisco Manuel de Melo, que teceu elogio à competência de Temudo numa carta de 24 de agosto de 1650.22 À respeito do envenenamento do Bispo, afirmou Temudo que

judeus se vão ao Brasil, e lá vivem à sua vontade sem temor da justiça eclesiástica, a qual é tão desacatada e desprezada por falta de ministros, que por este respeito padecem muitas afrontas assim bispos como seus ministros, que de ordinário são pessoas que vivem com o tempo por assim conservarem as vidas, e suposto tenham muitas vezes notícia de algumas coisas de que se deve fazer muito caso, não podem acudir como é necessário, e por esta causa morreu o bispo Dom Marcos Teixeira de Mendonça, de uma purga que lhe deram os judeus, temendo-se do zelo com que acudia atalhar a comunicação que tinham com os holandeses, a quem serviam com muitos refrescos da terra e comunicação que com eles tinham (...) Disse mais, que é público e notório que os cristãos novos, e em especial o médico Duarte Roiz Ulhoa, mataram com peçonha ao bispo Dom Marcos Teixeira, no ano de 1624, pouco mais ou menos, estando no arraial junto à Bahia, que estava ocupada dos holandeses, porque lhes tolhia que os não comunicassem nem lhes mandassem presentes, refrescos nem cartas, tomando-lhes algumas que se furtaram por morte do bispo, e Pedro Gonçalves de Matos, muito boa pessoa, cristão velho, e o [Antonio] Cordeiro médico, cristão novo, lhes disseram que o dito Duarte Roiz Ilhoa matara o bispo, e é notório isto lá. ${ }^{23}$

Alguns fatos concorrem para justificar a vesão do homicídio do prelado. O Bispo ainda era jovem, contando cerca de 46 anos, e, segundo Antonio Vieira, não parece que estava doente, visto que «caiu (...) em cama mais de cansaço e trabalho que de doença». Após os primeiros sintomas de fraqueza, o bispo viveu mais oito dias e morreu «estando no arraial junto à Bahia», na região atual de Itapagipe e foi sepultado próximo do local onde faleceu, na ermida de Nossa Senhora da Conceição. O testemunho de Manuel Temudo não deve ser entedido apenas como perseguição aos cristãos-novos, visto que um dos acusadores de Duarte Roiz Ulhoa foi o médico cristão-novo Antonio Cordeiro.

22 Diogo Barbosa Machado. Bibliotheca Lusitana, Lisboa, Na Officina de Ignacio Rodrigues, 1752, Vol. 3, p. 387; Manuel Temudo da FonseCA, Pars Prima. Decisiones et quaestiones Senatus Archiepiscopalis Metropolis Olysiponensis Regni Portugaliae ex gravissimorum patrum responsis collectae, tam in judicio ordinario quam apostolico a D. Emanuel Themudo da Fonseca, Ulysipone, ex officina Dominici Lopez Rosa, 1643. Secunda Pars e a Pars Tertia saíram pelo mesmo impressor, nos anos de 1644 e 1650, respectivamente. O Tomus Quartus foi publicado por Miguel Rodrigues em 1739.

${ }^{23}$ Arquivo Nacional da Torre do Tombo. Inquisição de Lisboa, Promotor, Caderno 15 - Livro 216, «Denunciações do licenciado Manoel Temudo», fls. 42-42v e 45-45v. Lisboa, maio de 1632.

Hispania Sacra, LXIII

127, enero-junio 2011, 155-184, ISSN: 0018-215-X 
O fato de parecer saudável, como afirma Vieira, apesar dos jejuns e noites insones, seguido pelas quenturas subsequentes e repentinas que foram descritas por Fr. Francisco, somada, por fim, a acusação feita por Temudo contra o médico Duarte Roiz Ulhoa, de que assassinou «com peçonha ao bispo Dom Marcos Teixeira» apresentam uma sequência de eventos que pode sinalizar, de fato, uma morte por envenamento.

Os indícios de que D. Marcos Teixeira de Mendonça foi assassinado devem ser considerados pela historiografia, apesar do fracasso das escavações arqueológicas realizadas em 1950 pela Prefeitura Municipal de Salvador, junto com uma comissão de historiadores, para tentar localizar a sepultura e, talvez, os restos mortais do referido Bispo. ${ }^{24}$

Qual seria, então, o veneno mais acessível na Bahia do século XVII? O veneno deveria ser conseguido localmente, visto que em 1624 o trânsito marítimo estava praticamente suspenso no Recôncavo. A circulação de pessoas e mercadorias, em meio a resistência contra os neerlandeses, ficou restrita às aldeias tupinambás do Recôncavo e qualquer substância produzida teve que ser feita com o conhecimento e os instrumentos desta cultura. Há, não obstante, dois venenos usuais aos índios do Recôncavo, com matéria-prima abundante e facilmente produzidos. O primeiro é o tucupí, suco da raiz da mandioca, que Gabriel Soares de Sousa descreve na Bahia em 1587, apesar de não utilizar esta nomeclatura. ${ }^{25}$ Este veneno também era conhecido dos índios do Vale do Amazonas, sendo tão ativo que «em poucas horas mata aos que bebem, ou sejão animais, ou homens, e contam excessivas dores, que parecem desfazerem as entranhas com ansias e convulsões espantosas. É mui doce e grato ao paladar». ${ }^{26} \mathrm{~A}$ velocidade de ação deste veneno indica que não teria sido utilizado contra o Bispo.

${ }^{24}$ Manoel de Aquino BarbosA, «O Sitio do Arraial e da Sepultura de D. Marcos Teixeira», Freguesia da Conceição da Praia 1623-1973: D Marcos Teixeira, Fundador, Salvador, Tipografia Beneditina, 1973, p. 149-155. As indicações documentais da sepultura foram incertas e contraditórias. Os trabalhos de escavação nas ruínas da ermida de Nossa Senhora da Conceição em Itapagipe, em 1950, não lograram qualquer resultado ao tentar identificar a sepultura de D, Marcos Teixeira. Várias ossadas humanas foram localizadas, mas não fora possível determinar se alguma delas pertenceu ao Bispo. É desconhecido, atualmente, o paradeiro dessas ossadas.

25 Gabriel Soares e SousA, Tratado Descriptivo do Brazil em 1587, Rio de Janeiro, Typographia Universal de Laemmert, 1851, pp. 164-165.

${ }^{26}$ João DAniel, Tesouro Descoberto no Máximo Rio das Amazonas, Livro II, Capítulo 4. Outro veneno do Vale do Amazonas é o timbó ou tinguy, chamado pelos espanhóis de barbasco, extraído do suco amargo da cortiça, com gosto quase impossível de ser camuflado. Sua ação é semelhante ao curare e o usuário tem morte quase imediata. Gastão Cruls na sua Hiléia Amazônica identifica quatro tipos de curares, no Alto Amazonas, no Alto Orinoco, na Guiana Inglesa e na Guiana Francesa, todos extraídos de plantas diversas do ramo Strychnos. O uso de plantas desta família não é registrado entre os tupinambá na Bahia. 
No Brasil, contudo, o uso do termo «peçonha» está associado a venenos extraídos de animais. $\mathrm{O}$ veneno das cobras deve ser eliminado de antemão pelas óbvias dificuldades em conseguí-lo e porque as culturas indígenas locais não faziam uso destes animais. O veneno mais utilizado no Recôncavo baiano, também descrito por Gabriel Soares de Sousa, é encontrado nos sapos-cururús (Bufo marinus) ou sapos de Espanha, sendo extraído do fígado e da pele do animal «da qual o gentio usa quando quer matar alguem». ${ }^{27}$ A matéria-prima para este veneno é abundante no Recôncavo. Esse animal produz e excreta, por glândulas espalhadas pelo corpo, um líquido branco com substâncias conhecidas como bufotoxinas. O efeito do veneno é cardiotóxico e seus componentes básicos podem ser classificados segundo sua toxicodinâmica como: adrenalina; noradrenalina; bufotenina, dihidrobufotenina e bufotionina.

Os efeitos da bufotenina e bufotionina são similares aos de uma intoxicação suave, com efeito estimulante, incluindo leves alucinações que duram menos de uma hora. A ingestão deste conjunto de substâncias, em contrapartida, é letal. Os sinais cardíacos associados são cianose, fraqueza, colapso, edema e convulsões. Pode ocorrer emese e diarréia. ${ }^{28}$

Supondo que D. Marcos Teixeira foi de fato envenenado, os indícios fazem crer que seu assassino utilizou veneno extraído do sapo. Inclusive as «quenturas» que o acometeram, indicadas na presente Relação, podem ser associadas aos sintomas de envenenamento. A sepultura do Bispo nunca foi localizada e, por isso, a hipótese de assassinato não pode ser comprovada. Esta hipótese, contudo, também não pode ser descartada, até mesmo por conta dos muitos desafetos que o Bispo conseguiu angariar quando proibiu, sob pena de excomunhão e execução sumária, o comércio e assistência aos soldados da WIC encerrados em Salvador.

Duarte Roiz Ulhoa, contudo, não teve registro de alguma queixa formalizada contra ele perante o Santo Ofício e não foi enquadrado por crime de lesa-majestade quando D. Fradique de Toledo restaurou Salvador, ocasião em que ordenou a execução de cinco colaboracionistas. Ulhoa estava vivo em 1646

${ }^{27}$ Gabriel Soares e SousA, Tratado Descriptivo do Brazil em 1587, p. 266.

${ }^{28}$ Davis WeIL, «Bufo alvarius: a potent hallucinogen of animal origin», Journal of Ethnopharmacology, Volume 41(n.1-2), Elsevier, 1994. pp. 1-8. Os antropólogos especulavam a razão de diversas culturas indígenas na América utilizar o sapos em rituais, como demonstram representações iconográficas e mitológicas de sapos, além de grande número de reportes etinográficos acerca destes anfíbios. Davis Weil apresentou a hipótese que as representações e reportes são referentes, não ao Bufo marinus, por conta da toxidade de seu veneno, mas sim ao Bufo alvarinus que produz um potente alucinógeno, 5-methoxy-N,N-dimethyltryptamine (5-MeO-DMT). O autor demonstra que a tóxina deste sapo pode ser consumida oralmente ou aspirada, sendo classificada como uma droga de classe 1 pelas leis australianas, a mesma classe da heroína e da cocaína. No caso do Bufo marinus, a morte é inevitável por ingestão ou contato do seu veneno com a corrente sanguínea.

Hispania Sacra, LXIII

127, enero-junio 2011, 155-184, ISSN: 0018-215-X 
quando foi novamente acusado durante a Grande Inquirição na Bahia, organizada naquele ano. Novamente foi alvo de denúncias e teve seu nome associado, outra vez, à manipulação de substâncias químicas, aparecendo sob denúncia de curandeirismo.

O que pôde ser apurado a respeito de Ulhoa é que teve sua filha condenada à fogueira pelo Santo Ofício em Lisboa. A jovem se chamava Teresa e uma das denúncias contra seu pai em 1646 é de dedicar à filha morta uma capela com invocação de Santa Teresa em Jacarecanga, escandalizando os moradores do Recôncavo. O Bispo D. Pedro da Silva de Sampaio lhe negou a autorização para erigir a capela. Outro filho de Ulhoa, Lopo Roiz Ulhoa, foi sambenitado pelo Santo Ofício, mas retornou para a Bahia em maio de 1642.29

O texto de Fr. Francisco de San Juan não encerrar as discussões acerca da invasão neerlandesa em 1624. Pelo contrário, sua publicação reacende a antiga controvérsia, existente desde o primeiro dia da tomada de Salvador, acerca da colaboração de criptojudeus com os invasores da WIC. As graves acusações de Fr. Francisco e do Padre Temudo afirmam que Duarte Roiz Ulhoa eliminou o comandante-em-chefe da resistência contra os neerlandeses. Nada, contudo, foi dito acerca das causas que o levaram a supostamente assassinar D. Marcos Teixeira, se por motivação pessoal ou política. O significado maior da Relação de Fr. Francisco de San Juan é demonstrar que a história e a historiografia da invasão neerlandesa da Bahia em 1624 e a restauração no ano seguinte, pela armada luso-espanhola, chefiada por D. Fradique de Toledo, ainda possuem lacunas a serem esclarecidas e fatos que merecem ser investigados.

\section{TRANSCRIÇÃO PALEOGRÁFICA}

\section{Fl. 21}

Relasão da perda da Bahia por fr. frco de são / João descalço da ordem de S. frco. Fl 22

o autor deste papel se chama / o P. fr. frco de são João descalço de S. frco Fl. 23

Da tomada da Cidade da Bahia, e o que mais

Socedeo ate a morte do señor Bispo.

Em o mes de Abril da era de mil y seissẽ / tos e vinte e quatro veio hum recaudo a esta Cidade / de huma vila, que chamão Boipeba ao gouernador / Dio-

\footnotetext{
${ }^{29}$ Arquivo Nacional da Torre do Tombo, Inquisição de Lisboa, Promotor, Caderno 29 - Livro 228, «Grande Inquirição», fls. 10v, 29v e 59, Lisboa, abril a agosto de 1646.
} 
go de Mendoça, que estaua hũa nao onde cha- / mão o Morro con duas lanchas, e que toda a noi - / te estaua con ferol, vendo isto o Gouernador mã - / dou recado para que a gente de fora se iuntasse, e / uiesse toda para a cidade, a que seruisse para a de- / fender. A gente iunta, que conforme se deçia seriam / perto de tres mil e quinhentas pesoas. Mando o / Gouernador fazer prestes dois Patachos, e em cada / hum gente, que os podesse defender, fazendo Capitão / de hum, a hum seu filho chamado Ant.o de Men - / donça, e do otro a hum mercador da Illa de Ma - / deira, e mandoos partir e delle ordem, não para to - / mar a Nao, nem remeter a ella, mas para ver se / podiam tomar as duas lanchas, q erão as q fazião / todo mal, e para elle em pesoa ir tomar a nao por ser ella / muyto grande, e trazer muytas pesoas, e gente $[\mathrm{Fl} .23 \mathrm{v}]$ e isto se sobe tambem por hũa nao q vinha de An - / gola para a cidade, a qual a nao tomou, e não / lhe fes mal nenhum mas antes a mandou para a / Cidade, porq como não trazião, senão negros e elles / não e mercadoria, que lhe serue a deixarão. Forão / os dois Patachos, e andarão la algũns dias, mas / como o tempo se mudou ao lessueste a nao se foi para / o mar por amor de não perigar. Tornarãose os dois / patachos, visto não auer nada, e o tempo lhes ser / tan contrario, o Gouernador em os vendo na Baia / mandou que tornasem logo ao mar so pena de mor - / te. Tornarão como lhes foi mandado, e aquela / noite se fizerão na volta do mar, e todo aquelle / dia, e a tarde se virão entre os enimigos, e como / erão tantos não conhecerão os patachos cuydando que / erão seus, e hũa nao, q vinha de lisboa tambem / se escapo, e se vierão a Cidade dar conta ao Gouer- / nador do q pasaua, e tinhão visto.

\section{De Como o Gouernador se fes prestes, e como} a armada dos enimigos entro na Bahia.

A oito de Maco apareserão na barra a armada / dos enimigos, e não entrarão aquelle dia por o tempo / não ser $m .{ }^{\text {to }}$ fauorable, e tambem como otros dizem / por não estarem todas juntas, e esperarem por las / mais, e assim aquelle dia não entrarão, mas a o outro / que forão noue dia de são Gregorio as noue da manhã / entrarão [Fl. 24] entrarão pola Bahia todas por sua ordem hũa apos otra / todas con suas bendeiras olandesas, e con toldos ver- / melhos, e desta maneira sem apareser pesoa al - / guma en sima da Cuberta derão hũa volta por la / Bahia, como se a tiverão medida aos palmos; das / noue ate as onze estiuerão en cala, e logo man - / darão hum betel con gente com hũa bandeira olan- / deza: este vinha conforme elles depois diserão tra- / ziam embaixada, que não farião mal nenhum se / lhe decem licença para contratar e vender suas fazẽ- / das assim como de Portugal as trazião. O Gouerna - / dor tanto viu que o batel vinha para terra, e cuy- / dando o q podia ser, e que sua embaxada seria de / nenhum efeito lhe mandou atirrar duas pesas; e elle / tanto que viu q lhe atirauão virou, e tirou dois calho- / naços, que trazia. O Gouernador mandou por a / gente toda por su 
ordem andando elle de hũa parte / a otra con muyta deligencia: mandou as naos, que / no porto estauão polas por sua ordem, inda que com / mao conselho, porque aonde as pos não fizerão nada: / comesarão os enimigos a tirar alguns tiros os piores / e de menos força; os nossos comesarão atirar de / huma fortaleza, q o gouernador tinha meia feita, e / não deixarão de lhe fazer algum mal destorçandolhe / algumas naos, e vendo elles que as pesas da fortaleça / lhe fazião m.to dano o iuntarão todos os bateis e cheos [Fl. 24v] de gente balrroarão a fortaleza, ainda q não puderão / por que se defenderão os que dentro estauão valerosam. te / vendo elles, que não podião tomar a fortaleza puserão / quatro naos iunto della, e para que os pelouros que / atirauão the não fizesem m. . $^{\text {to }}$ dano, derão en seco cõ / as naos, coisa, que espantou a todos, e dahi comme- / çarão a desparar de tal $\mathrm{m} .{ }^{\text {ra }}$ que não hauia quem a- / guardasse na fortaleza, polo $\mathrm{m} .^{\text {to }}$ dano $\mathrm{q}$ fazião aos nos - / sos, e os nossos tambem lhe fazião, e lhe matauão / m. ta gente; tornarão a cometer a fortaleza, e uen- / do os nossos, que não podião mais defendela a deixa- / rão, ainda que ficou o filho do Gouernador, e Lorenço / de Brito, que ficando sos o fizerão $\mathrm{m}$. ${ }^{\text {to }}$ bem matando- / he $\mathrm{m} .{ }^{\text {ta }}$ gente, e quando mais não puderão se sairão; / entrarão os enimigos, e como elles não tinhão repa- / ro nem fortaleza, porque de Terra lhe matauão muy- / ta gente caruarão as pesas para q não pudessem atirar / mais, e se forão as naos. Os nossos vendo isto torna- / rão a fortaleza, e vendo que não se podiam seruir das / pesas as botarão no mar para q os enimigos se não pode- / sem seruir dellas. Continuarão elles em atirar ate / noite; e antes della forão a tomar as naos, que esta- / uão peleiando, e as tirarão donde estauão con morte / de algũns dos seus, e tanto, que anoiteseo, o gouernador / mandou por fogo as otras que ficauão pera que elles se não / aporueitacem dellas, e os enimigos tanto, q anoiteseo não / tirarão [F]. 25] tirarão mais, inda que de quando en quando tirauão hũa / pesa.

De como os enimigos deixarão quatro naos na entrada da barra para combater, e tomar a fortaleza de s. Ant. ${ }^{\circ}$ e do que mais sosedeu

Esta hũa fortaleza na entrada da Barra / q chamão de $\mathrm{s}^{\text {to }}$ Ant..$^{\circ}$ hũa legoa da Cidade e de bem / poco efeito para os enimigos, porq como a barra he de / tres legoas de boca se afastão os enimigos dela por / lo otro lado, e assim não lhe fazem mal as pesas / de artelleria. Os Olandeses vendo que por nenhuma / parte podian botar gente para tomar a cidade senão / ali por ser huma boa praia pera desembarcar deixa- / rão quatro naos las milhores, y de mais força, $\mathrm{p}$. a / que tomado a fortaleza lançarem gente commesa- / rão a atirar e a botar a fortaleza por terra cõ grande / fuerça; os nossos o fazião como milhor podiam, porque / la fortaleça tinha $m .{ }^{\text {to }}$ poca artelharia e menos gente, / y assi a não podião empedir, que não desembarcasem; / os nossos que con duas bandeiras estauam a guardan- / doos os fizerão otra ves embarcar, vendo elles isto tor- / narão com muy- 
ta mas gente, que fue necessario aos / nossos retirarse: vendo elles sem empedim. ${ }^{\text {to }}$ comme- / sarão logo en un lugar, q ahi esta, a q chamão villa [Fl. 25v] Velha, por ser a p. ${ }^{\text {ra }}$ Pouoacão da Bahia em sua fundação / ahi robarão o que acharam, e os Templos sagrados q- / brando santos, e profanando os ornam. tos Dali se vi- / erão chagando pera a Cidade de tal $m .{ }^{\text {ra }}$ que en se sarrã- / do a noite se puserão onde chamão são bento un tiro de / arcabus da Cidade e asentarão seu arrail sem seren / sentidos e troxerão quatro pesas de Artelharia q / desem-

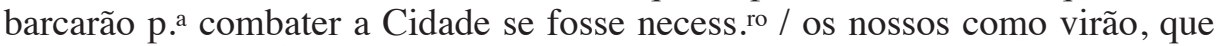
não se podião defender se hião / acolhendo, e tanto, que virão a noite o fizerão mi- / lhor, porque as molheres ia erão saidas, e a mais / gente commua; ia o Gouernador andaua fora de si / sem sentido, vendo que a Cidade se hauia de tomar, por / q a gente o desemparaua, e assim quando veio a / maña se achou con

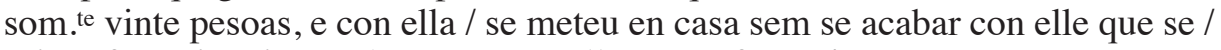
saisse fora visto ia não hauer rem.o; elle se confesou / para morrer se o matassem os enimigos, porque elle / isso deseiaua, vendo q a fortuna assi lhe daua en / rosto.

Vendo os enimigos que por la maña a cidade es- / taua desemparada commesarão a marchar . $^{\mathrm{a}}$ ella vin- / do sempre atirando, porq cuydarão elles, q os nossos / lhe tinhão feito alguma emboscada; vierão a praça / y assentarão seu arraial, e forão as casas do Gouer- / nador onde estaua com obra de 20 pesoas o Gouernador / se fes [Fl. 26]se fes por defender, inda que logo lhe abaterão as ar- / mas, e o leuarão prezo com os mais as naos, e esti- / uerão para lhe cortarem a cabeza.

Do que mas sosedeu e do desacato que fizerão as cousas Sagradas.

Em os enimigos tomando o Cou..$^{\text {to }}$ de s. Bento q esta fora / da Cidade, e foi o p. ${ }^{\text {ro }}$ templo en que entrarão ahi comme- / sarão sua furia maior em as coisas sagradas os s. ${ }^{\text {tos }}$ quebra- / rão, de m. ${ }^{\text {ra }}$ que san Bento lhe derão muytas cuchilha- / das; o santo Amaro lhe tirarão cõ sugidade de gente / a Virgen sra mã a fizerão em retalhos, e assim fo- / rão fazendo ao mais, que acharão sem perdoar a coisa

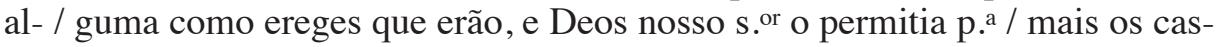
tigar; em entrando como emtrarão em a Cida- / de puserão suas postas em aonde virão ser necess. ${ }^{\text {ro }}$ e com- / mesarão a saquear a Cidade ia viuua, e deserta sem se- / us moradores como otra jerusalem que acharão muy- / ta riqueza assi

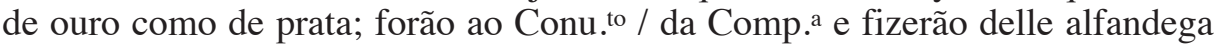
metendo seus robos / nelle, e fazendo dos santos o que fizerão dos mais, q / os vassos sagrados, e ornam. tos tirarão todos os religiosos / das religiõis deixando o mais do Conu.$^{\text {to }}$, inda q os Cle- / rigos se ouuerão con mais descuydo, porq si no fue / algũa confraria, que seus irmãos tiuerão lembrança [Fl. 26v] não se tirou nada da see fizerão sua Mesquita quebrando / os santos, e os vassos sagrados 
fazendo delles como se não / forão; dos ornam. ${ }^{\text {tos }}$ fazião vestidos, e de la estola ligas e / bandas; de nossa srã Da iuda fizerão tauerna metendo / nella os viños, que na Cidade estauão, de San frn.co fize- / rão atafona, e moião o trigo que de Olanda trazião, e / os santos de vulto lhe seruião de asentos em que se asen - / tauão, e moraua hum Capitão en o Conu. ${ }^{\text {to }}$ con sua Comp. ${ }^{\text {a }}$ / de soldados; do Carmo fizerão atalaia, e vigia por es- / tar fora da Cidade em hum alto donde se descubria $m .^{\text {to }}$, dos / santos fizerão pior, porq do Cristo dos passos troxerão a- / tado cõ a corda por o pescoso polo chão dando lhe de cu- / theladas, e os otros santos o mesmo: isto he o que fize- / rão logo em sua entrada, e despues executauão mai - / res crueldades nas imageñs que achauão pellas cassas.

\section{De Como a gente se saia da Cidade e como elles se fizerão fortes.}

Vendo a gente quam poco rem. ${ }^{\circ}$ tinha contra estes / tam crueis enimigos era lastima de ver tanta g.te fora / de huma Cidade, a saber donzelhas, meninos, e mo- / lheres prenhes, que por esses campos parião, q era / lastima, pois doentes q da cama se ergião, e lhe / faltaua todo o regalo andando por os matos a pe; pois os / feridos, que da peleia fugirão, e alguns con as tripas nas / mãos [Fl. 27] mãos; serto q era p. ${ }^{a}$ hauer lastima, e todos atribuião / isto a seus peccados, que na verdade no foi outra / coussa, polo desaforo con que se viuiuia na Cidade, nis- / to q tocaua ao peccado da carne: a donzelha andaua / perguntando pela may; a molher pelo marido, e / assi tudo era hũa confuzão, porque como sairão de / noite cada hum hia para onde asertaua; e assi os / p.ros dias padeserão muytas miserias, e necessidades / de fome, e a cama era a terra, e se o Brasil não / fora tam quente, e temperado como he morrera $/ \mathrm{m} .^{\text {ta }}$ gente de frio, porq $\mathrm{m}$.tos dias dormião pelos cam- / pos; porq o medo con que hião lhe paresião que / vinham os enimigos de tras de si; os frades todos / fazião o mesmo, e em verdade q estauamos nos / dezertos e que tres dias não soubemos q cousa / era comer mais q hũns pos de farinha de pão.

Enquanto a gente andaua cõ este medo os eni- / migos se fortificarão na Cidade murandoa o milhor / que puderão, porque ella não estaua murada, e pon- / dolhe $m .{ }^{\text {tas }}$ pesas de artelheria, de $m .{ }^{\text {ra }}$ que fizerão, / o q nos hauiamos de fazer, e para mais segura / $m .^{\text {te }}$ estarem tinhão suas vigias fora da Cidade, on- / de chamão o Carmo, e tomarão a repreza de hũa a- / goa para q a gente não pudesse passar a Cidade, e / fesse hũa alagoa tam grande, q hũa não da India [Fl. 27v] pudera facilm.te nadar nella, e assi tinhão elles cõ / tudo suas postas, e vigias. Foi tam grn. ${ }^{\text {de }}$ o despoio / que da Cidade leuarão, q o não posso cõ palabras en/ careser por ser muy rica a Terra, e da $\mathrm{m} .{ }^{\text {to }} \mathrm{de} \mathrm{si} /$ polo muyto asucar, pao do Brazil, e otras m. ${ }^{\text {tas }}$ cou- / sas; de asucar que na Cidade, e nauios acharão fo- / rão mais de duas mil caixas, e m. ${ }^{\text {to }}$ pao do Bra- / zil, e fumo; e assi despacharão logo quatro / naos carregadas de tudo o milhor q na Cidade acha- / rão, e nelas 
foi o Gouernador, e seu filho, e m.tos / religiosos, q tomarão, q vinhão em nauios de al- / gumas cidades, e portos do Brazil, e não sabião o / que da Cidade era feito, e desta m.ra tomarão m.tos / nauios, assi de Portugal como de otras m.tas partes / por ser o Brazil hum dos maiores portos de contra- / to que ha.

Como o senõr Bispo aiunto a gente e fes hum hum arraial para que os enimigos não pasasem nem saisem fora da Cidade.

Vendo o senõr Bpõ D. Marcos Teixeira q / a gente con o medo hia toda fugindo, e os enimigos hião / cobrando animo, e se atreuião ia a sair fora da Ci- / dade as fazendas, não se contentando com os robos da / eabeça que pudese isto da Cidade aiun- / to [Fl. 28] to gente, visto não hauer cabeça q pudesse isto fazer / mando Religiossos aonde elle não podia ir auizando a / todos se iuntassem, para que os enimigos não cobrassem / tanto brio, veio a gente, inda q desarmada por não ter / poluora nem arcabuzes, mas não the faltaua $o$ ani- / mo pera peleiarem, e na verdade o fizerão algũns tão- / bem, que parese querião igualar aqueles antiguos / portugueses em o esforço, e valentia; o s.r Bpõ a to- / dos consolaua e animaua, cõ o que ria, ria; cõ o q / choraua, choraua: de $\mathrm{m} .{ }^{\text {ra }} \mathrm{q}$ a todos sabia leuar como / Pastor, e prudente que era; aiuntou obra de

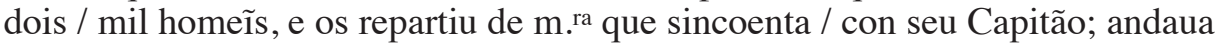
aos asaltos vinte dias vin- / do aquelles iuão otros; todos os dia hauia sermão / que o s. ${ }^{r}$ Bpõ / fazia em o araial con tanto fauor, e / espiritoz q mais paresia aos ouuintes sermão de / paixão: estes homeñs q en estes asaltos andauão o / fazião muy bem, e como os olandezes estauão a / custumados a sair fora, e achauão encontro hauia / braua peleia de parte a parte, inda que elles sem- / pre leuauão o pior; hũas vezes lhe matauão os nossos / vinte, otras des; em fim otras o que podião, de $\mathrm{m} \cdot{ }^{\text {ra }} \mathrm{q} / \mathrm{sempre}$ os nossos, o matauão, o catiuauão, porq $\mathrm{m} .{ }^{\text {tos }}$ tra- / ião viuos, e elles confesauão o q hauia na Cidade e / quem os mandara vir, e o señor Bpõ p. ${ }^{a}$ que mais [Fl. 28v] obrigasem daua premios a quem mataua hum framen- / go, e toda a gente q no raial estaua a sostentaua a sua / costa, mandando vir prouim. ${ }^{\text {to }}$ de diuersas $p .{ }^{\text {es }}$ y corria / tanto a fama, q de sento e vinte legoas veio hũ homem / m. ${ }^{\text {to }}$ rico con oitenta homeñs som. ${ }^{\text {te }}$ ao seruir: mando / o señor Bpõ botar bando, que todos os ameziados por / qualq ${ }^{\text {ra }}$ delito pudaesem liurem. ${ }^{\text {te }}$ vir p. ${ }^{\text {a }}$ o arraial q. ${ }^{\circ}$ / elle em nome de sua Magestade lhe perdoaua asis- / tindo cõ sua pesoa no arraial, e asaltos, o q logo todos / fizerão tambem daua aluaras, e fazia caualheros fi- / dalgos a quem fazia algũa boa sorte $\mathrm{p} .^{\mathrm{a}}$ assi os obri- / gar cõ honrra, e com prémios, quando o não fize- / sem pelo amor de Ds, que e o aluo, a que / todas nossas cousas auemos de atirar, e emcaminhar. 


\section{De Como o señor Bpõ aiuntou gente pera tomar a Cidade.}

Dia de s. $^{\text {to }}$ Ant. ${ }^{\circ} \mathrm{q}$ he a treze de junho do mes- / mo ano, vendo o señor Bpõ que tinha m..$^{\text {ta }}$ gente iun- $/ \mathrm{ta}, \mathrm{e} \mathrm{m} \cdot{ }^{\text {ta }}$ ia morta aos enimigos em os asaltos de / terminou de ver se podia dar na Cidade, e pera / isso ordenou q fosse dia de . $^{\text {to }}$ Ant.$^{\circ}$, indo com a g. te / a manha do santo forão sentidos de hũa atalaia / que elles tinhão posto no Conu. ${ }^{\text {to }}$ do Carmo, e o sinal / que lhe tinhão dado os enimigos he q tocase o sino / como [Fl. 29] como o fizerão, fizerãose elles laprestes, e os nossos / abalrroarão as portas do Conu.$^{\text {to }}$ e forão aos dormitorios / onde em as seldas estauão quatro homeñs con suas mo- / lheres, e defendendose dos nossos tudo o que puderão; os / nossos matarão dois os outros tomarão vivos, e os tro- / xerão ao señor eBpõ, os quais em sua prezença / os nossos os matarão sem elle o poder defender; tanto / que veo a manhã sairão os Olandeses ao rebate / que a sua talaia tinha feito cõ o sinal do sino, inda / q o pagou lindam.${ }^{\text {te }}$ porque estando tangendo lhe a- / rou hum dos nossos, e o deixou estirado em o tilhado / da Igreia; sairão pois logo pela manhã, e os nossos / os fizerão outra ves meter na Cidade cõ morte de m. tos / e lhe deixarão a porta aberta, mas como os nossos / lhe tinhão dito, que elles tinhão feito $m .{ }^{\text {tas }}$ minas de / poluora arrasiarão, que em entrando os queimmasẽ / a todos pelo q ouue conselho que por então lhe não pa- / sasem mas adiante, e se recuarão atras ficando / o s. ${ }^{\mathrm{r}}$ Bispo muy pesarozo de ser sentido, porq o não / o ser lhe tomara a Cidade pelo modo, e traça, q leua- / rão; dos nossos alguñs vierão feridos, mas oie nhũm / morreo, q não foi pequeno milagre entre tantos / e metidos os nossos entre elles, porq ouue homem / q chegou a porta da Cidade, e pregou lança nela; / $29 \mathrm{v}]$

Dos mais asaltos ate morte do señor Bpõ, e co-

mo lhe matarão o seu General que elles sentirão muyto.

Tornou o s.r Bpõ a gente ao raial donde saira / y dahi lhe fazia seus asaltos como dantes saião elles / hum dia, e os nossos lhe matarão muytos, e os que / tomarão viuos lhe cortauão os braços, e atados ao pes / cosos lhos mandarão a Cidade, e o Capitão nosso os mã- / dou desafiar, o que elles aseitarão mas não so por so mas / viendo obra de quatrosentos, e tinhão hũa silada em / o caminho

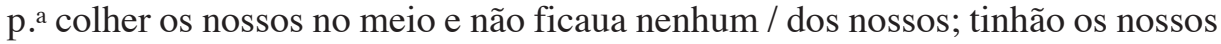
feito hũa emboscada / em a praya que chamão de Tapagipe, porq tinhão / nouas q todas as tardes hia o seu general a hũa for- / taleza que elles ali tinhão, foi assi que foi a ca- / ualo con dois filhos pequenos, que tinha, e / a guarda vinha bem atras, e descuydados do que / lhe podia aconteser, os nossos tanto que virão occa- / Sião sairão, e matarão ao General, e os filhos se / lhes acolherão, inda q hum foi de tal $\mathrm{m}$. ${ }^{\text {ra }}$ fe- / rido, que logo morreo na Cidade, a guarda quando / acu- 
dio [Fl. 30] acodio ia elle estaua em o Inferno fizerão grande sen- / tim. to e se o tomarão viuo, cuydo q dandoo largarão / a Cidade, mas não pode ser menos, porq vinha a / guarda atras que se o não matauão logo o perdirião / os nossos, e

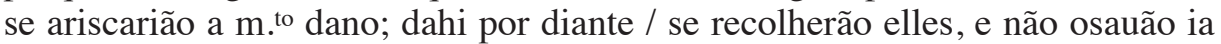
sair da Cida- / dade quanto he por terra, porq vião q lhe mata- / uão os nossos $m$. $^{\text {ta }}$ gente, que conforme dezião serião / os mortos perto de duçentos, e viuos alguñs vinte, $\mathrm{q} /$ por essas fazendas ficauão quando me eu vim p. ${ }^{a}$ Es- / paña; con tudo os nossos não deixauão seu exercicio / de emboscadas, porque ainda alguñs se desmandauão / e se vinhão buscar a morte, porque em saindo ne- / nhum escapaua por seus peccados, e alguñs dos nossos / que a Cidade hião as escondidas e tornauão trazendo / que lhes era necess. ${ }^{\text {ro }}$ ia indo não os deixauão tornar, e asi cauentauão irem por mar as fazendas com suas / naos, mas tambem lhe sosedia o que na Cidade, in- / da que algumas vezes trazião alguma pilhagem / não deixaua de lhe costar a morte de m. ${ }^{\text {tos; }}$ uzarão / elles de uma emuensão, que foi os negros de am- / gola, que se meterão com elles alguñs boatuão di- / ante, mas como elles de seu são muy cobardes / logo virarão as costas, e os nossos fazião braua / matança nelles, de m.ra que nem por mar ia quando / eu vim andauão. [Fl. 30v]

\section{Da morte do senõr Bpõ, e de algũas cou-} sas que aconteserão mais.

Andaua ia o senõr Bpõ tam cansado dos traba- / lhos, que o Capitão mor de Pernambuquo Matias de / Albuquerque que lhe mandou hũ Capitão, q seruisse / em seu lugar, homẽ expermentado, em cousas de / guerras mas como a gente estaua cõ o sr Bpõ tam con- / tente foi mal recebido, e se o señor Bispo con sua pru- / dencia, e santidade não apasiguara não cuydo, q / o recibirião. Comesou a gouernar o nouo Capitão pro- / seguindo o q o s. ${ }^{r}$ Bpõ auia começado, inda q não cõ / tal sprito con que elle o fazia, vendose o señor Bpõ / fora de tal carga e trabalho asas de cansado se reco- / lheo a hũa cassa de hũ bom homẽ, q o 4 recolheo / con toda a caridade con que suas poses o podião fazer, / comesou logo a se achar mal de hũas quenturas; vi- / erão os medicos, que se poderão achar, o qual foi hũ / iudeu, porq por nossos peccados elles so os são os q es- / tudão medesina, esse o encerrou, comesou logo a / sangralo, a tirar sangue adonde o não hauia, e / logo lhe deu em tresualios de maneira q ao ou- / tauo dia lhe deu hũa purga, e ao decimo o enterrou, / q todos diserão que lhe derão pesonha, e não podia / ser menos, porq se virão m. tas mostras de lha terem / dada; grande foi o sentim..$^{\text {to }}$ de todos; não hauia escrauo / nem [Fl. 31] nem pequeno, nem grande, q não chorase sua morte / pois ficauão orfãns de tal Pay, emterrarãono bẽ / pobrem. ${ }^{\text {te }}$ não conforme a Bpõ, porq não auia ordem / pera isso; grande foi a festa, que os enimigos fizerão / tanto que o souberão na Cidade, pues lhe hia tanto q / se elle não fora não sey o como nos pasaramos, porque / os enimigos se metião 
ia pela terra, e os nossos pela / necessidade q padeçião alguñs hião a Cidade buscar o q / lhe faltaua, e o sr Bpõ acudio como Pastor a suas / ouelhas, inda que elle não tinha obrigasão se não de / se recolher em algũa Igreia.

De algũas cousas que aconteseram no tempo da peleia

Por remate de tudo não quero deixar de con- / tar algũas cousas notaueis, que no tempo da peleia / aconteserão aos religiossos, pois como os enimigos em- / trarão na Bahia cõ suas naos, e os nossos commesarão / sua peleia; os perlados de das religiõis mandarão / seus religiossos, pera q confesasem, e animasem a / gente, e os que não erão confesores senão simples / sacerdotes os mandarão apresentar ao Bpõ p. ${ }^{\mathrm{a}}$ que / confesasem, e animasem a todos como o fizerão, a hum / de s. frn.co estando confesando a hum homem veo hũa / bala, e lhe caiu no habito sem the fazer nenhum [Fl. 31v] mal; a outro estaua asoluendo a hũ quando vem hum / pelouro de pesa, e emq to $^{\text {o }}$ homem abaixa a cabeca p. a / o absoluerem pasa a bala, e o não abaixar o leuaua / a outro lhe deu hũa em os peitos e não lhe fes mal / nenhum, de maneira q se tinha por milagre, porque / como andauão em obras de caridade confesando, e ani- / mando nehũ perigou sendo elles o que andauão no / mayor perigo, e entre as ballas pasando de hũa

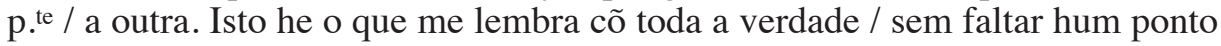
de todo o q aqui digo.

Na transcrição paleográfica, o texto foi mantido de acordo com o manuscrito guardado na Biblioteca Nacional de España. Para a transcrição adaptada para o linguagem atual, adotei os seguintes princípios:

1. A supressão de todas as maiúsculas desnecessárias;

2. Desenvolvimento das abreviaturas: «q» foi transcrito «que»; «porq» foi transcrito «porque»;

3. O til usado no último elemento dos ditongos nasais foi restabelecido no primeiro elemento destes, por exemplo: «naõ» foi transcrito «não»; quando usado como sinal de consoantes nasais ( $m$ e $n$ ), foi suprimido ou substituído pela respectiva consoante; conforme o caso;

4. Foram eliminados os grupos de consoantes hoje em desuso e foi necessário substituir a letra «u» pelo «V»

5. Restabelecidos os acentos conforme o uso dos nossos dias;

6. Restabelecida a forma ortográfica contemporânea das desinências verbais;

7. A toponímia foi atualizada;

8. Adotou-se a pontuação contemporânea, sem deturpar o texto, isto é, suprimindo as vírgulas inúteis; 
9. A divisão do manuscrito em parágrafos foi respeitada, assim como algumas características da prosa do autor pelo seu viés arcaizante, como «valerosamente»e «donde»;

10. As palavras em castelhano foram traduzidas para português.

\section{TRANSCRIÇÃO ATUALIZADA}

\section{Fl. 21}

Relação da perda da Bahia por Fr. Francisco de São João descalço da ordem de S. Francisco.

Fl 22

O autor deste papel se chama o Padre Fr. Francisco de São João descalço de S. Francisco

Fl. 23

Da tomada da Cidade da Bahia, e o que mais

Sucedeu até a morte do senhor Bispo.

Em o mês de Abril da era de mil e seiscentos e vinte e quatro, veio um recado a esta cidade de uma vila, que chamam Boipeba, ${ }^{30}$ ao Governador Diogo de Mendoça, que estava uma nau onde chamam o Morro ${ }^{31}$ com duas lanchas, e que toda a noite estava com farol, vendo isto o Governador mandou recado para que a gente de fora se juntasse, e viesse toda para a cidade, a que servisse para a defender. A gente junta, que conforme se descia, seriam perto de três mil e quinhentas pessoas. Mandou o Governador fazer prestes dois patachos, e em cada um gente, que os pudesse defender, fazendo Capitão de um, a um seu filho chamado Antonio de Mendonça, e do outro a um mercador da Ilha de Madeira, e mandou-os partir e deu-lhe ordem, não para tomar a nau, nem remeter a ela, mas para ver se podiam tomar as duas lanchas, que eram as que faziam todo mal, e para ele em pessoa ir tomar a nau por ser ela muito grande, e trazer muitas pessoas, e gente, [Fl. 23v] e isto se soube também por uma nau que vinha de Angola para a cidade, a qual a nau tomou, e não lhe fez mal nenhum mas antes a mandou para a cidade, porque como não traziam, senão negros, e eles não são mercadoria que lhe serve, a deixaram. Foram os dois patachos, e andaram lá alguns dias, mas como o tempo se mudou ao lés-sueste, a nau se foi para o mar por amor de não perigar. Tornaram-se os dois patachos, visto não haver nada, e

${ }^{30}$ A vila de Boipeba foi estabelecida numa ilha do Arquipélago de Tinharé, cercada de um lado pelo oceano e de outro pelo estuário do Rio do Inferno.

${ }^{31}$ Morro de São Paulo situado na Ilha de Tinharé, atual município de Cairú. 
o tempo lhes ser tão contrário, o Governador em os vendo na Baía mandou que tornassem logo ao mar sob pena de morte. Tornaram como lhes foi mandado, e aquela noite se fizeram na volta do mar, e todo aquele dia, e a tarde se viram entre os inimigos, e, como eram tantos, não conheceram os patachos cuidando que eram seus, e uma nau, que vinha de Lisboa, também se escapou e se vieram a cidade dar conta ao Governador do que passava e tinham visto.

De como o Governador se fez prestes, e como a armada dos inimigos entrou na Bahia.

A oito de março apareceram na barra a armada dos inimigos, e não entraram aquele dia por o tempo não ser muito favorável, e também como outros dizem por não estarem todas juntas, e esperarem por as mais, e assim aquele dia não entraram, mas a o outro que foram nove, dia de São Gregório, às nove da manhã entraram [Fl. 24] pela Bahia, todas por sua ordem uma após outra, todas com suas bendeiras holandesas, e com toldos vermelhos, e desta maneira sem aparecer pessoa alguma em cima da coberta deram uma volta pela Bahia, como se a tiveram medida aos palmos; das nove até as onze estiveram em cala, ${ }^{32} \mathrm{e}$ logo mandaram um batel com gente com uma bandeira holandesa: este vinha, conforme eles depois diseram, traziam embaixada, que não fariam mal nenhum se lhe dessem licença para contratar e vender suas fazendas assim como de Portugal as traziam. O Governador tanto viu que o batel vinha para terra, e cuidando o que podia ser, e que sua embaixada seria de nenhum efeito lhe mandou atirar duas peças; e ele tanto que viu que lhe atiravam virou, e tirou dois canhonaços, que trazia. O Governador mandou por a gente toda por sua ordem andando ele de uma parte a outra com muita deligência: mandou as naus, que no porto estavam pelas por sua ordem, ainda que com mal conselho, porque aonde as pôs não fizeram nada: começaram os inimigos a atirar alguns tiros, os piores e de menos força; os nossos começaram a atirar de uma fortaleza, que o Governador tinha meio feita, ${ }^{33}$ e não deixaram de lhe fazer algum mal destorçandolhe algumas naus, e vendo eles que as peças da fortaleza lhe faziam muito dano, juntaram todos os batéis e cheios [Fl. 24v] de gente abalrroaram a fortaleza, ainda que não puderam poque se defenderam os que dentro estavam valerosamente vendo eles, que não podiam tomar a fortaleza puseram quatro naus junto dela, e para que os pelouros que atiravam the não fizessem muito dano, deram em seco com as naus, coisa, que espantou a todos, e daí começaram a disparar de tal maneira que não havia quem aguardasse na fortaleza, pelo muito dano que faziam aos nossos, e os nossos também lhe faziam, e lhe matavam muita gente; tornaram a cometer a fortaleza, e vendo os nossos, que não podiam mais

\footnotetext{
32 Em silêncio.

${ }^{33}$ Forte da Lagem, atualmente aterrado sob o bairro do Comércio, na Cidade Baixa, em Salvador.
} 
defendê-la a deixaram, ainda que ficou o filho do Governador, e Lourenço de Brito, que ficando sós o fizeram muito bem matando-lhe muita gente, e quando mais não puderam se saíram; entraram os inimigos, e como eles não tinham reparo, nem fortaleza, porque de terra lhe matavam muita gente, cravaram ${ }^{34}$ as peças para que não pudessem atirar mais e se foram as naus. Os nossos, vendo isto, tornaram a fortaleza e vendo que não se podiam servir das peças as botaram no mar para que os inimigos se não pudessem servir delas. Continuaram eles em atirar até noite; e antes dela, foram a tomar as naus, que estavam pelejando, e as tiraram donde estavam com morte de alguns dos seus, e tanto, que anoiteceu, o Governador mandou por fogo as outras que ficavam, para que eles se não aproveitassem delas, e os inimigos tanto que anoiteceu não atiraram [Fl. 25] mais, ainda que de quando em quando atiravam uma peça.

\section{De como os inimigos deixaram quatro naus na entrada da barra para combater, e tomar \\ a fortaleza de Santo Antonio e do que mais sucedeu}

Está uma fortaleza na entrada da Barra que chamam de Santo Antonio, ${ }^{35}$ uma légua da cidade e de bem pouco efeito para os inimigos, porque como a barra é de três léguas de boca, se afastam os inimigos dela por o outro lado, e assim não lhe fazem mal as peças de artilharia. Os holandeses vendo que por nenhuma parte podiam botar gente para tomar a cidade, senão ali por ser uma boa praia, para desembarcar deixaram quatro naus as melhores, e de mais força, para que tomado a fortaleza, lançarem gente; começaram a atirar e a botar a fortaleza por terra com grande força; os nossos o faziam como melhor podiam, porque a fortaleza tinha muito pouca artilharia e menos gente, e assim a não podiam impedir, que não desembarcassem; os nossos que com duas bandeiras estavam aguardando-os, os fizeram outra vez embarcar, vendo eles isto, tornaram com muito mas gente, que foi necessário aos nossos retirar-se: vendo eles sem impedimento começaram logo em um lugar, que aí está, a que chamam Vila [Fl. 25v] Velha, por ser a primeira povoação da Bahia em sua fundação, aí roubaram o que acharam, e os templos sagrados quebrando santos, e profanando os ornamentos. Dalí se vieram chegando para a cidade de tal maneira que em se cerrando a noite se puseram onde chamam São Bento, um tiro de arcabuz da cidade e assentaram seu arraial sem serem sentidos e trouxeram quatro peças de artilharia, que desembarcaram para combater a cidade, se fosse necessário; os nossos como viram, que não se podiam defender, se iam acolhendo, e tanto, que viram a noite o fizeram melhor, porque as mulheres já eram saídas, e a mais gente comum; já o Governador andava fora de si, sem sentido, vendo que a cidade se havia de tomar, por que a gente o desamparava, e assim

\footnotetext{
${ }^{34}$ No original: caruarão

${ }^{35}$ Forte de Santo Antonio da Barra, atual Farol da Barra.
} 
quando veio a manha, se achou com somente vinte pessoas, e com elas se meteu em casa sem se acabar com ele, que se saísse fora visto já não haver remédio; ele se confessou para morrer se o matassem os inimigos, porque ele isso desejava, vendo que a fortuna assim the dava em rosto.

Vendo os inimigos que pela manhã a cidade estava desamparada, começaram a marchar para ela, vindo sempre atirando, porque cuidaram eles, que os nossos lhe tinham feito alguma emboscada; vieram a praça e assentaram seu arraial, e foram as casas do Governador onde estava com obra de 20 pessoas, o Governador se fez [Fl. 26] por defender, ainda que logo lhe abateram as armas, e o levaram preso com os mais as naus, e estiveram para lhe cortarem a cabeça.

\section{Do que mas sucedeu e do desacato que fizeram as cousas sagradas.}

Em os inimigos tomando o Convento de S. Bento ${ }^{36}$ (sic) que está fora da cidade, e foi o primeiro templo em que entraram, já começaram sua fúria maior em as coisas sagradas, os santos quebraram, de maneira que São Bento lhe deram muitas cutiladas, o Santo Amaro lhe atiraram com sujidade de gente, a Virgem Senhora Mãe a fizeram em retalhos, e assim foram fazendo ao mais, que acharam sem perdoar a coisa alguma como hereges que eram, e Deus nosso senhor o permitia para mais os castigar; em entrando como entraram em a Cidade puseram suas postas aonde viram ser necessário e começaram a saquear a cidade já viúva, e deserta sem seus moradores, como outra Jerusalém que acharam muita riqueza, assim de ouro como de prata; foram ao Convento da Companhia ${ }^{37}$ (sic) e fizeram dele alfândega metendo seus roubos nele, e fazendo dos santos o que fizeram dos mais, que os vasos sagrados, e ornamentos tiraram todos os religiosos das religiões, deixando o mais do Convento, ainda que os clérigos se houveram com mais descuido, porque se não foi alguma confraria, que seus irmãos tiveram lembrança [Fl. 26v] não se tirou nada da Sé; fizeram sua mesquita, quebrando os santos e os vasos sagrados, fazendo deles como se não foram; dos ornamentos faziam vestidos, e da estola, ligas e bandas; de Nossa Senhora da Ajuda fizeram taverna, metendo nela os vinhos, que na cidade estavam, de São Francisco fizeram atafona, e moiam o trigo que de Holanda traziam, e os santos de vulto lhe serviam de assentos, em que se assentavam, e morava um Capitão em o Convento, com sua companhia de soldados; do Carmo fizeram atalaia e vigia por estar fora da cidade, em um alto donde se descobria muito, dos santos fizeram pior, porque do Cristo dos Passos trouxeram atado com a corda por o pescoço pelo chão, dando lhe de cutiladas e os outros santos o mesmo: isto é o que fizeram logo em sua entrada, e depois executavam maiores crueldades nas imagens que achavam pelas casas.

\footnotetext{
${ }^{36}$ Mosteiro de São Bento.

${ }^{37}$ Colégio da Companhia de Jesus.
} 
De como a gente se saía da cidade e como eles se fizeram fortes.

Vendo a gente quão pouco remédio tinha contra estes tão cruéis inimigos, era lástima de ver tanta gente fora de uma cidade, a saber donzelas, meninos e mulheres prenhas, que por esses campos pariam, que era lástima, pois doentes que da cama se erguiam, e lhe faltava todo o regalo, andando por os matos a pé; pois os feridos, que da peleja fugiram, e alguns com as tripas nas [Fl.27] mãos; certo que era para haver lástima, e todos atribuíam isto a seus pecados, que na verdade não foi outra cousa, pelo desaforo com que se vivia na cidade, nisto que tocava ao pecado da carne: a donzela andava perguntando pela mãe; a mulher pelo marido e assim tudo era uma confusão, porque como sairam de noite cada um ía para onde acertava; e assim os primeiros dias padeceram muitas misérias, e necessidades de fome e a cama era a terra, e se o Brasil não fora tão quente e temperado como é, morrera muita gente de frio, porque muitos dias dormiam pelos campos; porque o medo com que iam lhe pareciam que vinham os inimigos de trás de si; os frades todos faziam o mesmo, e em verdade que estavamos nos desertos e que três dias não soubemos que cousa era comer mais que uns pós de farinha de pão.

Enquanto a gente andava com este medo, os inimigos se fortificaram na cidade, murando-a o melhor que puderam, porque ela não estava murada, e pondo-lhe muitas peças de artilheria, de maneira que fizeram, o que nos haviamos de fazer, e para mais seguramente estarem, tinham suas vigias fora da cidade, onde chamam o Carmo, e tomaram a represa de uma água para que a gente não pudesse passar a cidade, e fez-se uma lagoa tão grande, que uma nau da Índia [Fl. 27v] pudera facilmente nadar nela, e assim tinham eles com tudo, suas postas e vigias. Foi tão grande o despojo que da cidade levaram, que o não posso com palavras encarecer por ser mui rica a terra, e dá muito de si pelo muito açúcar, pau do brasil, e outras muitas cousas; de açúcar que na cidade e navios acharam foram mais de duas mil caixas, e muito pau do brasil, e fumo; e assim despacharam logo quatro naus carregadas de tudo o melhor que na cidade acharam, e nelas foi o Governador, e seu filho, e muitos religiosos, que tomaram, que vinham em navios de algumas cidades, e portos do Brasil, e não sabiam o que da cidade era feito, e desta maneira tomaram muitos navios, assim de Portugal como de outras muitas partes por ser o Brasil um dos maiores portos de contrato que há.

Como o senhor Bispo ajuntou a gente e fez um arraial para que os inimigos não pasassem nem saíssem fora da cidade.

Vendo o senhor Bispo D. Marcos Teixeira que a gente com o medo ía toda fugindo, e os inimigos iam cobrando ânimo e se atreviam já a sair fora da cida- 
de às fazendas, não se contentando com os roubos da cidade ajuntou [Fl. 28] gente, visto não hauer cabeça que pudesse isto fazer, mandou religiosos aonde ele não podia ir, avisando a todos, se juntassem para que os inimigos não cobrassem tanto brio, veio a gente, ainda que desarmada por não ter pólvora nem arcabuzes, mas não lhe faltava o ânimo para pelejarem, e na verdade o fizeram alguns tão bem, que parece queriam igualar aqueles antigos portugueses em o esforço, e valentia; o senhor Bispo a todos consolava e animava, com o que ria, ria; com o que chorava, chorava: de maneira que a todos sabia levar como pastor, e prudente que era; ajuntou obra de dois mil homens, e os repartiu de maneira que cincoenta com seu Capitão; andava aos assaltos vinte dias, vindo aqueles, iam outros; todos os dias havia sermão que o senhor Bispo fazia em o arraial com tanto favor, e espírito que mais parecia aos ouvintes sermão de paixão: estes homens que em estes assaltos andavam, o faziam mui bem, e como os holandeses estavam acostumados a sair fora, e achavam encontro, havia brava peleja de parte à parte, ainda que eles sempre levavam o pior; umas vezes lhe matavam os nossos vinte, outras dez; enfim outras o que podiam, de maneira que sempre os nossos o matavam, ou cativavam, porque muitos traziam vivos, e eles confessavam o que havia na cidade e quem os mandara vir, e o senhor Bispo para que mais [Fl. 28v] obrigassem dava prêmios a quem matava um flamengo, e toda a gente que no arraial estava, a sustentava à sua custa, mandando vir provimento de diversas partes e corria tanto a fama, que de cento e vinte léguas veio um homem muito rico com oitenta homens somente ao servir: 38 mandou o senhor Bispo botar bando, que todos os amasiados por qualquer delito pudessem livremente vir para o arraial quando ele em nome de sua Majestade lhe perdoava, assistindo com sua pessoa no arraial, e assaltos, o que logo todos fizeram, também dava alvarás e fazia cavalheiros fidalgos, a quem fazia alguma boa sorte para assim os obrigar com honra e com prêmios, quando o não fizessem pelo amor de Deus, que é o alvo, a que todas nossas cousas havemos de atirar e encaminhar.

\section{De como o senhor Bispo ajuntou gente para} tomar a cidade.

Dia de Santo Antonio que é a treze de junho do mesmo ano, vendo o senhor Bispo que tinha muita gente junta, e muita já morta aos inimigos em os assaltos, determinou de ver se podia dar na cidade e para isso ordenou que fosse dia de Santo Antonio, indo com a gente a manhã do santo foram sentidos de uma atalaia que eles tinham posto no Convento do Carmo e o sinal que lhe tinham dado os inimigos é que tocasse o sino como [Fl. 29] o fizeram; fizeram-se eles

${ }^{38}$ Este homem foi o jovem Salvador Correia de Sá e Benevides, enviado para a Bahia por Martim de Sá, governador do Rio de Janeiro, acompanhado por 80 soldados e 100 guerreiros indígenas. 
lá prestes, e os nossos abalrroaram as portas do Convento e foram aos dormitórios onde em as celas estavam quatro homens com suas mulheres, e defendendo-se dos nossos tudo o que puderam; os nossos mataram dois, os outros tomaram vivos e os trouxeram ao senhor Bispo, os quais em sua presença, os nossos os mataram sem ele o poder defender; tanto que veio a manhã saíram os holandeses ao rebate que a sua atalaia tinha feito com o sinal do sino, ainda que o pagou lindamente, porque estando tangendo lhe arou ${ }^{39}$ (sic) um dos nossos, e o deixou estirado em o telhado da Igreja; sairam, pois, logo pela manhã e os nossos os fizeram outra vez meter na cidade, com morte de muitos e lhe deixaram a porta aberta, mas como os nossos lhe tinham dito, que eles tinham feito muitas minas de pólvora arrasiarão (sic), que em entrando os queimassem a todos, pelo que houve conselho, que por então lhe não passassem mais adiante e se recuaram atrás ficando o senhor Bispo mui pesarozo de ser sentido, porque o não o ser lhe tomara a cidade pelo modo e traça que levaram; dos nossos alguns vieram feridos, mas hoje nenhum morreu, que não foi pequeno milagre entre tantos e metidos os nossos entre eles, porque houve homem que chegou a porta da cidade e pregou lança nela; [Fl. 29v]

Dos mais assaltos até morte do senhor Bispo, e como lhe mataram o seu General que eles sentiram muito.

Tornou o senhor Bispo a gente ao arraial donde saíra e daí lhe fazia seus assaltos como dantes saíam eles um dia, e os nossos lhe mataram muitos, e os que tomaram vivos lhe cortavam os braços, e atados ao pescoços lhes mandaram a cidade, e o Capitão nosso os mandou desafiar, o que eles aceitaram, mas não só por só, mas vindo obra de quatrocentos, e tinham uma cilada em o caminho para colher os nossos no meio e não ficava nenhum dos nossos; tinham os nossos feito uma emboscada em a praia que chamam de Itapagipe,,$^{40}$ porque tinham novas que todas as tardes ía o seu general a uma fortaleza ${ }^{41}$ que eles ali tinham, foi assim que foi a cavalo com dois filhos pequenos, que tinha, e a guarda vinha bem atrás, e descuidados do que lhe podia acontecer, os nossos tanto que viram ocasião saíram, e mataram ao General, e os filhos se lhes acolheram, ainda que um foi de tal maneira ferido, que logo morreu na cidade, a guarda quando acudiu [Fl. 30] já ele estava em o inferno fizeram grande sentimento, e se o tomaram vivo, cuido que dando-o largariam a cidade, mas não pode ser menos, porque vinha a guarda atrás que se o não matavam logo o perderiam os nossos,

\footnotetext{
${ }^{39}$ Varou ou parou.

${ }^{40}$ Península de Itapagipe, região que atualmente compreende os Alagados, a praia de Boa Viagem, o Bonfim, Monte Serrat, a Ribeira, o bairro do Uruguai e o bairro de Roma.

${ }^{41}$ Forte de São Bartolomeu da Passagem, localizava-se na ponta da Ribeira, próximo da foz do rio Pirajá, ao Norte da primitiva cidade de Salvador.
}

Hispania Sacra, LXIII

127, enero-junio 2011, 155-184, ISSN: 0018-215-X 
e se arriscariam a muito dano; daí por diante se recolheram eles, e não ousavam já sair da cidade quanto é por terra, porque viam que lhe matavam os nossos muita gente, que conforme diziam, seriam os mortos perto de duzentos, e vivos alguns vinte, que por essas fazendas ficavam quando me eu vim para Espanha; contudo os nossos não deixavam seu exercício de emboscadas, porque ainda alguns se desmandavam e se vinham buscar a morte, porque em saíndo nenhum escapava por seus pecados, e alguns dos nossos que a cidade iam as escondidas e tornavam trazendo que lhes era necessário já indo não os deixavam tornar, e assim aventavam ${ }^{42}$ irem por mar as fazendas com suas naus, mas também lhe sucedia o quê na cidade, ainda que algumas vezes traziam alguma pilhagem, não deixava de lhe custar a morte de muitos; usaram eles de uma invenção, que foi os negros de Angola, que se meteram com eles alguns botavam diante, mas como eles, de seu (sic) são mui covardes, logo viraram as costas, e os nossos fazião brava matança neles, de maneira que nem por mar já quando eu vim andavam. [Fl. 30v]

Da morte do senhor Bispo, e de algumas cousas que aconteceram mais.

Andava já o senhor Bispo tão cansado dos trabalhos, que o Capitão mor de Pernambuco Matias de Albuquerque que lhe mandou um Capitão, que servisse em seu lugar, homem experimentado, em cousas de guerras mas como a gente estava com o senhor Bispo tão contente, foi mal recebido e se o senhor Bispo com sua prudência e santidade não apaziguara, não cuido que o receberiam. Começou a governar o novo Capitão prosseguindo o que o senhor Bispo havia começado, ainda que não com tal espírito com que ele o fazia, vendo-se o senhor Bispo fora de tal carga e trabalho assaz de cansado se recolheu a uma casa de um bom homem, que o recolheu com toda a caridade com que suas posses o podiam fazer, começou logo a se achar mal de umas quenturas; vieram os médicos, que se puderam achar, o qual foi um judeu, porque por nossos pecados eles só os são os que estudam medicina, esse o encerrou, começou logo a sangrá-lo, a tirar sangue aonde o não havia, e logo lhe deu em tresvalios de maneira que ao oitavo dia lhe deu uma purga, e ao décimo o enterrou, que todos disseram que lhe deram peçonha, e não podia ser menos, porque se viram muitas mostras de lha terem dada; grande foi o sentimento de todos; não havia escravo nem [Fl. 31] nem pequeno, nem grande, que não chorasse sua morte pois ficavam orfãos de tal Pai, enterraram-no bem pobremente, não conforme a Bispo, porque não havia ordem para isso; grande foi a festa, que os inimigos fizeram tanto que o souberam na cidade, pois lhe ía tanto que se ele não fora, não sei o como nos passaramos, porque os inimigos se metiam já pela terra, e os nossos, pela ne-

\footnotetext{
42 No original: cauentauão.
} 
cessidade que padeciam, alguns iam à cidade buscar o que lhe faltava, e o senhor Bispo acudiu como Pastor a suas ovelhas, ainda que ele não tinha obrigação, se não de se recolher em alguma Igreja.

\section{De algumas cousas que aconteceram no tempo}

da peleja

Por remate de tudo, não quero deixar de contar algumas cousas notáveis, que no tempo da peleja aconteceram aos religiosos, pois como os inimigos entraram na Bahia com suas naus, e os nossos começaram sua peleja; os prelados das religiões mandaram seus religiosos para que confessassem e animassem à gente, e os que não eram confessores, senão simples sacerdotes, os mandaram apresentar ao Bispo para que confessassem, e animassem a todos como o fizeram, a um de São Francisco estando confesando a um homem veio uma bala, e lhe caiu no hábito sem lhe fazer nenhum [Fl. 31v] mal; a outro estava absolvendo a um quando vem um pelouro de peça, e enquanto o homem abaixa a cabeça para o absolverem passa a bala, e o não abaixar o levava, a outro lhe deu uma em os peitos e não lhe fez mal nenhum, de maneira que se tinha por milagre, porque, como andavam em obras de caridade confessando, e animando, nenhum perigou sendo eles o que andavam no maior perigo, e entre as balas passando de uma parte a outra. Isto é o que me lembra com toda a verdade, sem faltar um ponto de todo o que aqui digo. 